Márcio Ferro Catapani

\title{
O mercado de títulos públicos: Desmaterialização e circulação
}

Tese apresentada à

Faculdade de Direito da Universidade de São Paulo, para obtenção do título de doutor em Direito Comercial, sob orientação do Prof. Titular Newton De Lucca. 


\section{FOLHA DE APROVAÇÃO}

Márcio Ferro Catapani

O mercado de títulos públicos:

Desmaterialização e circulação

Tese apresentada à

Faculdade de Direito da Universidade de São Paulo, para obtenção do título de doutor em Direito Comercial.

Aprovado em:

\section{$\underline{\text { Banca Examinadora }}$}

Professor Dr.

Instituição:

Assinatura:

Professor Dr.

Instituição:

Assinatura:

Professor Dr.

Instituição:

Assinatura:

Professor Dr.

Instituição:

Assinatura:

Professor Dr.

Instituição:

Assinatura: 
A Vivian, por seu amor. 


\section{AGRADECIMENTOS}

Por certo, este trabalho não teria sido possível sem a ajuda e colaboração de diversas pessoas. Eis o momento de agradecer-lhes.

Ao Prof. Newton De Lucca, meu orientador, por ter me aceitado no curso de pósgraduação da Universidade de São Paulo, bem como pelos valiosos ensinamentos e sugestões que me transmitiu, em nossas conversas sobre o tema. Sua obra é, sem dúvida, uma das mais profundas que hoje existem sobre títulos de crédito e sobre negócios em meio eletrônico, motivo pelo qual muito pude aproveitar de sua orientação e de seus livros.

Aos Profs. Paula Andrea Forgioni e Paulo Borba Casella, que, na arguição de meu exame de qualificação, fizeram ponderações que muito ajudaram a melhorar o conteúdo do trabalho.

$\mathrm{Na}$ elaboração da pesquisa, tive a grata surpresa de receber a resposta rápida e esclarecedora a consultas formuladas a autoridades dos Estados Unidos da América e da Colômbia sobre os temas tratados. Assim, agradeço também a Carmen Moncada-Terry, da Securities and Exchange Comission - SEC, e a Juan Pablo Coy Navarro, da Superintendencia Financiera de Colômbia.

Aos Drs. Renato Spaggiari e Vivian Labruna Catapani, pela ajuda nas traduções. A colaboração e sugestões dos Drs. Humberto de Paula Lima Isaac e Mairan Maia também foram fundamentais para que pudesse ser aprofundada a reflexão sobre alguns temas.

Tenho ainda o dever de agradecer à minha família, pelo apoio e suporte que sempre me ofereceu quando cursava os créditos na faculdade e quando estava escrevendo este trabalho. Nos momentos de cansaço, nada teria sido possível sem eles.

Enfim, agradeço a todos os que, de alguma forma, direta ou indireta, colaboraram para tornar possível esta empreitada. 


\section{$\underline{\text { Cartularidade }}$}

PAPEL

E tudo que eu pensei

e tudo que eu falei

e tudo que me contaram

era papel.

E tudo que descobri

amei

detestei:

papel.

Papel quanto havia em mim

e nos outros, papel

de jornal

de parede

de embrulho

papel de papel

papelão.

\section{(Carlos Drummond de Andrade)}

\section{Literalidade}

La palabra es el hombre mismo. Estamos hechos de palabras. Ellas son nuestra única realidad o, al menos, el único testimonio de nuestra realidad.

(Octavio Paz. El lenguaje. In: El Arco y la lira)

\section{$\underline{\text { Autonomia }}$}

\section{CANÇÃO DO DIA DE SEMPRE}

(...)

Nada jamais continua,

Tudo vai recomeçar!

E sem nenhuma lembrança

Das outras vezes perdidas.

(...)

(Mário Quintana)

\section{$\underline{\text { Desmaterialização }}$}

Mi sono detto: Yambo, hai una memoria di carta. Non di neuroni, di pagine. Forse un giorno inventeranno una diavoleria elettronica che permetterà al computer di viaggiare attraverso tutte le pagine scritte dall'inizio del mondo a oggi, e di passare dall'una all'altra con un colpo di polpastrello, senza più capire dove ti trovi e chi sei tu, e allora tutti saranno come te.

(Umberto Eco, La misteriosa fiamma della Regina Loana) 


\section{RESUMO}

O Estado, para obter recursos com o objetivo de financiar suas atividades, recorre ao mercado por meio de dois mecanismos: a obtenção de empréstimos individualizados e o lançamento de títulos públicos. Na realidade atual, a dívida mobiliária alcança volume muito superior ao da contratual, tendo em vista algumas vantagens do mecanismo dos títulos públicos. Entre essas vantagens, pode-se citar um universo maior de potenciais compradores, a possibilidade de execução de política monetária, a maior facilidade de controle, o menor custo de negociação e escrituração. Fenômeno também observado nas últimas décadas, em escala mundial, é de que os títulos públicos sejam emitidos de modo escritural e eletrônico.

Nesse contexto, não pode ser aplicado a esses valores o ferramental teórico e normativo dos títulos de crédito. Com efeito, se a doutrina tradicional considerava os papéis emitidos pelo Estado como uma espécie desses títulos, tal constatação não mais se sustenta, em especial diante da completa inexistência de um suporte documental dos ativos eletrônicos. As características e institutos próprios dos títulos de crédito, como a cartularidade, a literalidade, o endosso e o aval não são compatíveis com a realidade negocial que hoje conforma os títulos públicos.

Um conceito jurídico que pode explicar a natureza atual dos títulos públicos e permitir o regramento das operações que os envolvem é o de instrumento financeiro. Desenvolvido no âmbito do ordenamento comunitário europeu, esse conceito não se encontra perfeitamente delimitado no ordenamento jurídico brasileiro, mas nada impede a sua construção em sede doutrinária.

Tomando por base a noção de instrumento financeiro, o foco da normatização deixa de ser cada título considerado em si, para recair sobre o mercado em que eles são negociados. Assim, ganha relevo o estudo da estrutura institucional desses mercados, bem como das principais operações que neles são travadas. Tais operações incluem a emissão e a oferta inicial, a negociação secundária, o resgate, a rolagem da dívida, bem como eventuais renegociações e alterações unilaterais nas características dos títulos. 
Para o desenvolvimento de mercados líquidos e eficientes, algumas condições são imprescindíveis, como, por exemplo, a existência de graus mínimos de estabilidade, previsibilidade e segurança, de uma imagem sólida e confiabilidade das instituições participantes, em especial dos entes estatais emissores etc. Além disso, todo o arcabouço normativo deve ser construído levando-se em consideração os interesses de cada grupo de agentes econômicos envolvidos, como forma de tornar atrativa para estes a alocação de recursos na aquisição de títulos públicos.

Palavras-chave: Títulos públicos. Mercado. Desmaterialização. Títulos de crédito. 


\begin{abstract}
When the State needs to obtain resources in order to finance its activities, it resorts to the market through two main mechanisms: individual loans or public securities. Nowadays, the debt securities total amount is much higher compared to the debts founded on individual loans, due to some advantages of the technology of public securities. Among such advantages, it can be mentioned a larger universe of potential buyers, the possibility of implementing monetary policy, the easier control, and the lower costs of trading and bookkeeping. In recent decades, it has also been noticed that the public bonds are worldwidely issued in both book-entry and electronic ways.
\end{abstract}

In this context, the theoretical and normative tools regarding negotiable instruments can not be applied to these bonds anymore. Indeed, if the traditional doctrine used to consider the public bonds as negotiable instruments, such understanding can no longer take place, specially taking into account the complete absence of any supporting documentation of electronic assets. The peculiar characteristics and rules related to the negotiable instruments, such as the need of the document to enforce the rights, the respect to the terms of the document, the endorsement, and the guaranty are no longer compatible with the present reality of public bonds.

A legal concept that can explain the current nature of the public securities and allows the regulation of operations envolving them is the financial instrument. Developed under the European Community law, this concept is not well defined in the Brazilian legal system yet, but nothing prevents its development in our doctrine.

Based on the concept of financial instruments, the focus of regulation is no longer each title considered itself, but the markets in which the financial instruments are traded. Thus it becomes important to study the institutional structure of such markets, as well as the leading operations that are performed in the markets' scope. Such operations include the issuance and the initial offering, the secondary trading, the redemption, the debt rollover, the renegotiations of the bonds, and the unilateral changes of their characteristcs. 
In order to develop efficient and liquid markets, certain conditions are essential, such as the existence of minimal degrees of stability, predictability and security; a solid image and reliability of the participating institutions, in particular of the public issuing bodies etc. Moreover, any regulatory framework should be built taking into consideration the interests of each economic agents groups involved, in order to make the allocation of resources in government securities attractive for them.

Keywords: Government bonds. Market. Dematerialization. Negotiable Instruments. 


\section{RIASSUNTO}

Lo Stato, quando vuole ottenere le risorse per finanziare le sue attività, si rivolge al mercato attraverso due meccanismi: i contratti di mutuo individuali e la collocazione di titoli pubblici. Oggidì, il debito pubblico basante su titoli è molto più elevato di quello derivante di contratti, a causa di alcuni vantaggi del meccanismo dei titoli pubblici. Fra questi vantaggi, si possono citare un universo più ampio di potenziali acquirenti, la possibilità di far attuare la politica monetaria, una maggiore facilità di controllo, il costo inferiore della negoziazione e della contabilità. Negli ultimi decenni ci si è accorto che i titoli pubblici in tutto il mondo sono stati emessi in modo dematerializzato ed elettronico.

In questo contesto, gli strumenti teorici e normativi dei titoli di credito non possono essere applicati a queste obbligazioni. Infatti, la dottrina tradizionale reputava i titoli di Stato come una sorta di titolo di credito, ma questo atteggiamento non è più sostenibile, soprattutto a causa della totale assenza di un documento che incorpori gli attivi elettronici. Le caratteristiche e le istituzioni proprie dei titoli di credito, come cartularità, letteralità, girata e avallo, non sono compatibili con la realtà attuale delle negoziazione di titoli pubblici.

Un concetto giuridico che può spiegare la natura attuale dei titoli pubblici e consentire il regolamento delle loro operazioni di negoziazione è lo strumento finanziario. Sviluppato sotto la legislazione della Comunità europea, questo concetto non è definito in modo adeguato nel sistema giuridico brasiliano, ma nulla impedisce suo sviluppo in dottrina.

Ammesso il concetto di strumento finanziario, la priorità della regolamentazione si volge da ogni titolo in se stesso considerato al mercato nel quale essi sono negoziati. Rileva quindi studiare la struttura istituzionale di questi mercati, così come le principali operazioni che in essi sono svolte. Tali operazioni comprendono l'emissione e l'offerta iniziale, la negoziazione sul mercato secondario, il riscatto, il rinnovamento del debito, e le eventuali rinegoziazioni e modifiche unilaterali delle caratteristiche dei titoli. 
Per lo sviluppo di mercati efficienti e liquidi, alcune condizioni sono indispensabili, ad esempio, l'esistenza di livelli minimi di stabilità, prevedibilità e sicurezza, una solida immagine e l'affidabilità delle istituzioni partecipanti, in particolare le persone statali emittenti, ecc. Inoltre, qualsiasi quadro di regolamentazione deve essere costruito tenendo in considerazione gli interessi di ogni gruppo di operatori economici coinvolti, in modo da renderli interessante l'investimento di risorse per l'acquisto di titoli di Stato.

Parole chiavi: Titoli pubblici. Mercato. Dematerializzazione. Titoli di credito. 


\section{SUMÁRIO}

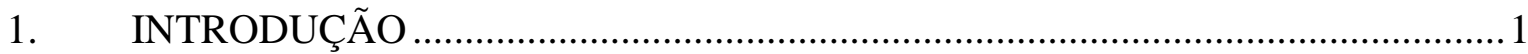

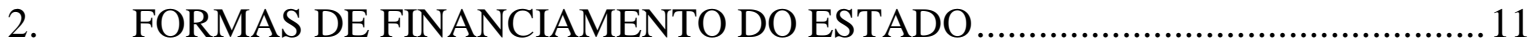

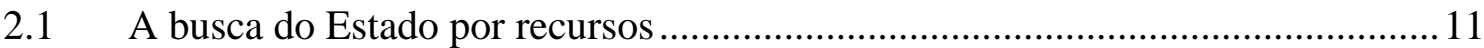

2.2 As formas de obtenção de empréstimos pelo Estado...........................................20

2.2.1 A opção pelos títulos públicos 23

2.2.2 A opção pelos títulos públicos eletrônicos 37

2.2.3 Classificação dos títulos emitidos pelo Estado 45

3. ANTECEDENTES HISTÓRICOS ……………………………………………....5

3.1 Evolução dos títulos públicos no Brasil..............................................................61

4. OS TÍTULOS PÚBLICOS COMO INSTRUMENTOS FINANCEIROS ………........78

4.1 Conceituação dos títulos de crédito ..................................................................78

4.2 Doutrina tradicional acerca da natureza dos títulos públicos: a caracterização

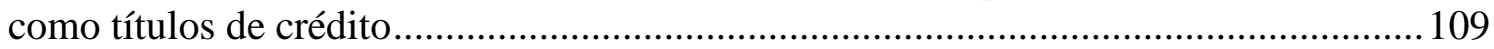

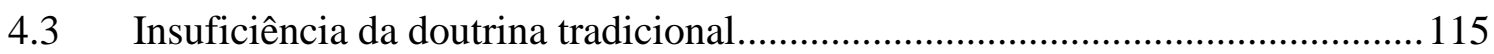

4.4 Os valores mobiliários: relações com os títulos públicos ....................................139

4.4.1 Os Certificados de Potencial Adicional de Construção - CEPACs 151

4.5 Breves notas sobre securitização e os títulos públicos ....................................... 155

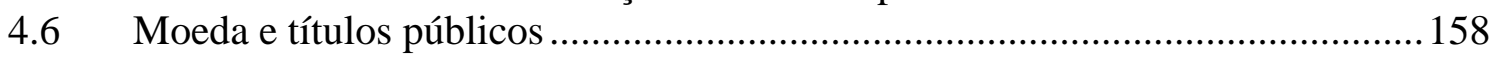

4.7 A categoria proposta: títulos públicos como instrumentos financeiros .............. 168

4.7.1 Os instrumentos financeiros nos textos normativos brasileiros 168

4.7.2 Os instrumentos financeiros no Direito comunitário europeu 171

4.7.3 Os instrumentos financeiros no Direito italiano 175

4.7.4 Os instrumentos financeiros no Direito português 182

4.7.5 Os instrumentos financeiros no Direito espanhol 188

4.7.6 Os instrumentos financeiros no Direito britânico 192

4.7.7 Os instrumentos financeiros no Direito francês 197

4.7.8 Os instrumentos financeiros no Direito estadunidense 199

4.7.9 Os instrumentos financeiros no Direito argentino 202

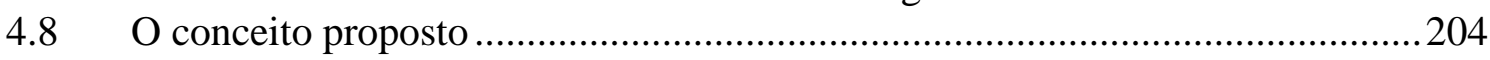

4.8.1 Cartularidade, documentalidade e títulos negociados em mercados próprios

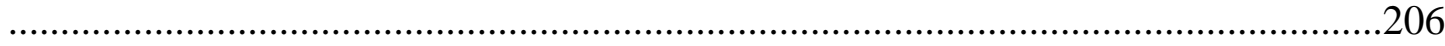

4.8.2 Mercados e mercados próprios 211

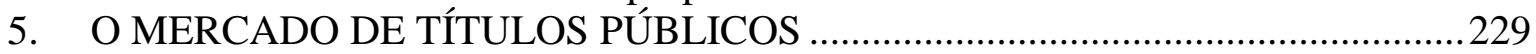

5.1 Condições para a existência de um mercado de títulos públicos.........................229

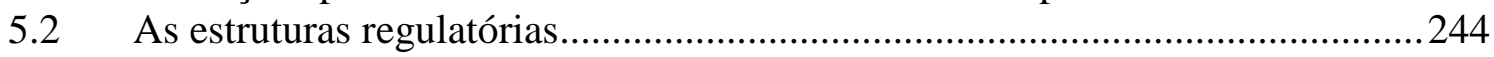

5.2.1 Fontes normativas estatais e a produção do Direito 244

5.2.2 As estruturas de negociação no mercado 248

5.2.3 A mútua implicação entre as estruturas privadas e públicas 254

5.3 Os interesses dos investidores

5.3.1 Investidores institucionais 259

5.3.2 Investidores não institucionais 268

5.4 Os principais negócios dos mercados regulados ..............................................22

5.4.1 Emissão e oferta inicial 278

5.4.2 Negociação secundária 291

5.4.2.1 Negociação secundária e autonomia 305

5.4.3 Resgate 308 
5.4.4 Rolagem da dívida 317

5.4.5 Renegociação da dívida e alterações unilaterais 324

6. ÓRGÃOS E ENTES RELACIONADOS À EMISSÃO E NEGOCIAÇÃO DE TÍTULOS PÚBLICOS

6.1 Constituição de 1988 - a estrutura do Estado brasileiro......................................332

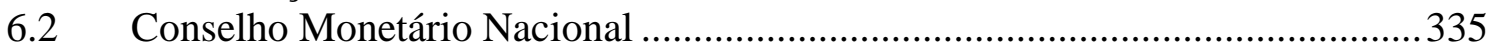

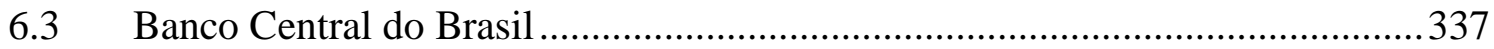

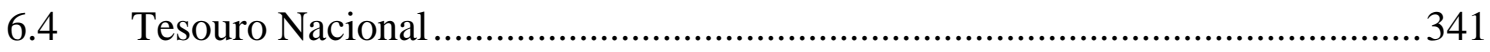

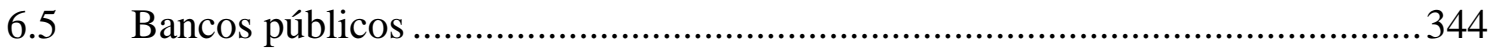

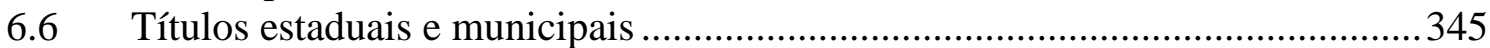

6.6.1 Fundos de Liquidez 348

7. ESPÉCIES DE TÍTULOS PÚBLICOS NO BRASIL E SUAS FUNÇÕES ..............350

7.1 Letras Financeiras do Tesouro - LFTs ……..................................................... 350

7.1.1 Letras Financeiras do Tesouro Séries A e B - LFTs-A e LFTs-B 353

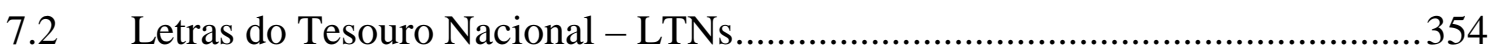

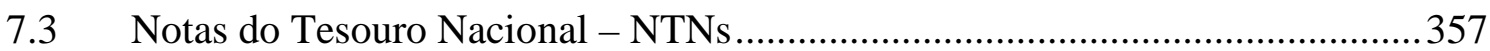

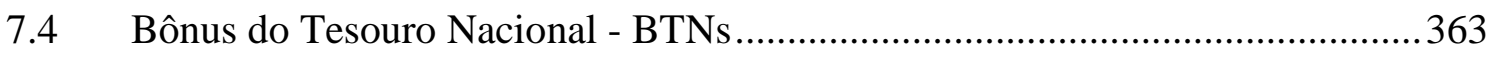

7.4.1 Brazil Investment Bonds - BIBs 368

7.4.2 Bônus do Tesouro Nacional Série Especial - BTNs-Série Especial369

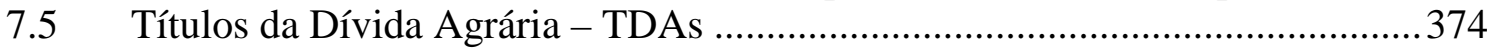

7.5.1 Títulos da Dívida Agrária para aquisição de imóveis rurais 383

7.6 Títulos para Alongamento da Dívida Agrícola - ASTNs ou ADAs ...................385

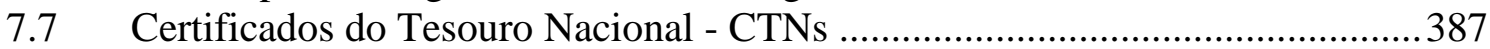

7.8 Certificados da Dívida Pública Mobiliária Federal - CDPs................................389

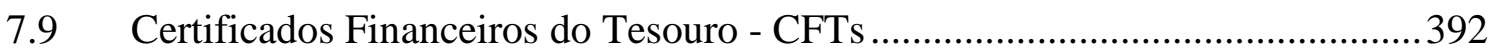

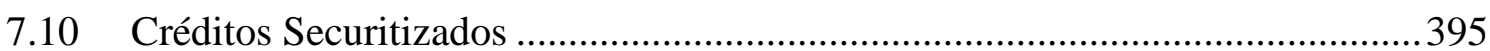

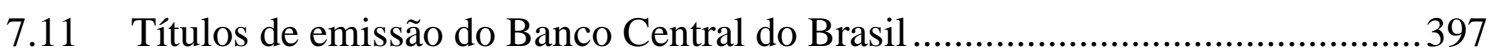

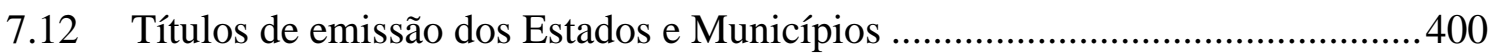

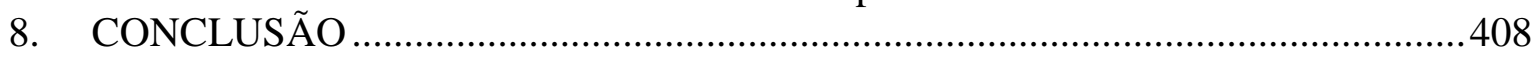

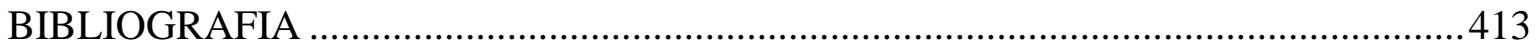

